\title{
Potential Probiotic Analysis: Indigenous Lactic Acid Bacteria from Freshly Drawn Goat Milk
}

\author{
Selvajeyanthi $\mathbf{S}^{1^{*}}$, Hemashenpagam $\mathrm{N}^{2}$, Vinotha $\mathbf{M}^{3}$ \\ ${ }^{1,3}$ Department of Microbiology, Tiruppur Kumaran College For Women, Tirupur, Tamil Nadu, India \\ ${ }^{2}$ Department of Microbiology, Hindusthan College of Arts and Science, Coimbatore, Tamil Nadu, India \\ *Corresponding Author: selvajeyanthi@gmail.com,
}

Available online at: www.isroset.org

Received: 09/May/2019, Accepted: 10/Jun/2019, Online: 30/Jun/2019

\begin{abstract}
The raw goat milk is a good source of potential probiotic microorganisms. In developing countries, the goat milk was consumed widely because of its therapeutic and nutritional values. The potential probiotic bacteria has some properties such as, survival in the gastrointestinal conditions like low $\mathrm{pH}$ and bile tolerance, production of antimicrobial compounds and adhesion to intestinal mucosa. Thirty Lactic acid bacteria (LAB) isolated from goat milk in Tirupur and Erode region. Among 30 isolates, the nine isolates were selected for studying the characterization of potential probiotic of LAB. So the screening process were carried out like cell hydrophobicity, phenol resistance, antioxidant assay, cholesterol reducing activity, auto and co-aggregation, acid and bile tolerance. The results obtained showed that the isolates G13 has high spectrum of action. This isolate were undergo to detect the bacteriocin activity, column chromatography and SDS-PAGE. G13 isolates showed inhibitory activity in well-diffusion assay when tested against E.coli and S.aureus. So, those inhibitory substances are characterized as antimicrobial proteins called bacteriocins. Further identification of bacteriocin produced by G13 was confirmed by SDS-PAGE, where it shows the low molecular weight protein $(17 \mathrm{kDa})$.
\end{abstract}

Keywords - potential probiotic, cell hydrophobicity, phenol resistance, antioxidant assay, SDS-PAGE

\section{INTRODUCTION}

Probiotics are defined as "living micro-organisms, which upon ingestion in certain numbers exert health benefits beyond inherent basic nutrition". FAO/WHO has adopted the definition of probiotics as "live microorganisms which when administered in adequate amounts confer a health benefit on the host" [1]. To achieve a probiotic status, microorganism must fulfil a number of criteria related to safety, functional effects and technological properties [2].

Lactic acid bacteria were utilized as natural preservatives in fermentation industry. It has advantageous health issue on host but the most important method is selection of strain based on physiological properties [3]. Lactic acid bacteria have the capacity to prevent the gastrointestinal tract from the pathogens. For pancreatic enzymes and other gastric secretions genus Lactobacillus show more resistant [4].

Ingestion of fermented goat milk amended antiatherogenicity in healthy cases: it sustained resistance of the lipoprotein fraction to oxidation, lowered levels of per oxidized lipoproteins, oxidized LDL, 8-isoprostanes and glutathione redox ratio and enhanced total antioxidant activity. The ingestion of fermented goat milk also varied both the preponderance and ratio of lactic acid bacteria species in the gut micro flora of the cases [5].

During metabolic process lactic acid bacteria produce a substance which act against pathogens and that substance is known as bacteriocin. Bacteriocins used in food industry for preserving the food products in natural way [6]. The sources for these probiotic strains are milk, meat and other fermented food products. The aim of the present study was to identify and characterize the novel bacteriocin producing lactic acid bacteria from raw goat milk.

\section{MethodologY}

The various raw goat milks were collected from different regions of Tirupur and Erode. The samples were cultured in the De Man Rogosa and Sharpe (MRS) agar media, after the growth of the organisms it were subjected to Gram staining, various biochemical tests. Based on non-haemolytic, antibiotic sensitive pattern, litmus assay and some of the strains were chosen for further probiotic characterization [7]. Such strains were S3, G5, G9, G13, G14, G15, G17, G26, and G27. 
Selection of isolates: The nine isolates of the lactic acid bacteria identified from various raw goat and sheep milk samples were taken to determine the potential probiotic properties.

\section{Cell surface hydrophobicity test [8]}

The degrees of hydrophobicity of the strains were determined by employing the method described as in [9]. This method was based on adhesion of cells to hexadecane droplets. Cultures were grown in $10 \mathrm{ml}$ MRS broth, centrifuged at $6,000 \mathrm{xg}$ for 5 minutes and the cell pellet was washed and resuspended in $10 \mathrm{ml}$ of Ringer solution $16 \% \mathrm{NaCl}, 0.0075 \%$ $\mathrm{KCl}, 0.01 \% \mathrm{CaCl}_{2}$ and $0.01 \% \mathrm{NaHCO}_{3}$ ). The absorbance at $600 \mathrm{~nm}$ was measured. Cell suspension was then mixed with equal volume of $n$-hexadecane and mixed thoroughly by vortexing for 2 minutes. The two phases were allowed to separate for 30 minutes and absorbance at $600 \mathrm{~nm}$ of the lower phase was recorded

The percentage hydrophobicity of strain adhering to hexadecane was calculated using the equation.

Hydrophobicity $(\%)=\frac{\mathrm{OD}_{600}(\text { initial })-\mathrm{OD}_{600}(\text { with hexadecane }) \times 100}{\left.\mathrm{OD}_{600} \text { (initial }\right)}$

Phenol resistance tests [10]

Overnight grown active cultures $(0.5 \mathrm{ml})$ were inoculated in MRS broth $(5 \mathrm{ml})$ tube to the concentration of phenol level $0.4 \%$ along with the respective control. The cultures were incubated at $37^{\circ} \mathrm{C}$. After 24 hours of incubation extent of growth was recorded by taking the absorbance at $600 \mathrm{~nm}$.

\section{Antioxidant Assay \\ DPPH Method [11]}

DPPH (Di Phenyl Picryl Hydroxide) activity test in which to a small amount of sample $0.1 \mathrm{ml}$ of DPPH solution was added and mixed well. To that, $400 \mu \mathrm{l}$ of $50 \mathrm{mM}$ Tris hydrochloric acid was added and incubated for about 30 minutes at room temperature and the results were determined at $517 \mathrm{~nm}$.

Total antioxidant Assay [12]

Take $1 \mathrm{ml}$ of sample to that add $1 \mathrm{ml}$ of the reaction mixture solution which contains the $0.6 \mathrm{M} \mathrm{H}_{2} \mathrm{SO}_{4}, 28 \mathrm{Mm}$ sodium phosphate and $4 \mathrm{Mm}$ ammonium molybdate, mixed well the sample and the reaction mixture were incubated at $50^{\circ} \mathrm{C}$ for 90 minutes at water bath. After that cool the mixture and the results were determined at $695 \mathrm{~nm}$.

\section{Cholesterol reducing activity [13]}

From the fresh culture take $1 \mathrm{ml}$ of cell free supernatant and then the volume of the supernatant is made up to $5 \mathrm{ml}$ by adding $\mathrm{FeCl}_{3} \cdot \mathrm{CH}_{3} \mathrm{COOH}$ reagent $(0.05 \%)$ and $3 \mathrm{ml}$ of concentrated sulphuric acid. After the sample were incubated for 20 minutes at room temperature. Take the absorbance at $560 \mathrm{~nm}$. The control should employed by the medium alone.

\section{Aggregation Study}

\section{Auto aggregation test [14]}

The isolates were grown in MRS broth or BHI broth, respectively, for $24 \mathrm{~h}$ at $37^{\circ} \mathrm{C}$. The cells were harvested by centrifugation $\left(7000 \mathrm{~g} 10 \mathrm{~min} 20^{\circ} \mathrm{C}\right)$ washed resuspended and diluted in sterile saline water $(0.85 \% \mathrm{NaCl} w / v)$ to obtain an OD660 $\mathrm{nm}=0.3$, determined using a spectrophotometer. After incubation for $60 \mathrm{~min}$ at $37^{\circ} \mathrm{C}$ cells were harvested $(300 \mathrm{~g}$

$2 \min 20^{\circ} \mathrm{C}$ ) and the OD660 $\mathrm{nm}$ of the supernatant were assessed accordingly. Auto aggregation was determined using the following equation:

$$
\text { Auto aggregation }(\%)=\left[\frac{O D_{0}-O D_{60}}{O D_{0}}\right] \times 100
$$

$\mathrm{OD}_{0}$ refers to the initial $\mathrm{OD}$, and

$\mathrm{OD}_{60}$ refers to the OD determined after $60 \mathrm{~min}$.

\section{Co-aggregation test [14]}

For the evaluation of co-aggregation the isolates were grown in $10 \mathrm{ml}$ of MRS broth at $37^{\circ} \mathrm{C}$. Cells were harvested after 24 h $\left(7000 \mathrm{~g} 10 \mathrm{~min} 20^{\circ} \mathrm{C}\right)$ washed resuspended and diluted in sterile saline water to OD660 $\mathrm{nm}=0.3$. The degree of coaggregation was determined by OD readings obtained for paired studied culture and co-aggregation partners suspensions (ratio of $500 \mu 1$ and $500 \mu 1$ of each suspension). Cells were harvested $\left(300 \mathrm{~g}, 2 \mathrm{~min}, 20^{\circ} \mathrm{C}\right)$, and the OD660 $\mathrm{nm}$ of the supernatant was determined. Coaggregation was calculated using the following equation

$$
\text { Co-aggregation }(\%)=\left[\frac{O D_{t o t}-O D_{s}}{O D_{t o t}}\right] \times 100
$$

$\mathrm{OD}_{\text {tot }}$ refers to the initial OD, taken immediately after the relevant strains were paired.

$\mathrm{OD}_{\mathrm{s}}$ refer to the $\mathrm{OD}$ of the supernatant obtained after 60 minutes of incubation.

\section{Antimicrobial activity [15]}

The agar over lay method was employed to determine the ability of the viable lactic acid bacteria strains to inhibit the growth of the indicator pathogens E.coli, Staphylococcus aureus and Candida spp. A loopful of LAB in MRS broth were inoculated on MRS agar plate as a thick line of about 2 $\mathrm{mm}$ and above $30 \mathrm{~mm}$ long at a good distance away from the edge of the plates and incubated under microaerophilic condition at $37^{\circ} \mathrm{C}$ for 24 hours. After incubation, the MRS agar plates were overlaid with approximately $0.2 \mathrm{ml} * 10^{7}$ $\mathrm{CFU} / \mathrm{ml}$ of an overnight broth culture of the test pathogens inoculated in $10 \mathrm{ml}$ of the Mueller Hinton Agar (with 0.7\% agar-agar). The overlays were allowed to set, and incubated at $37^{\circ} \mathrm{C}$ under aerobic condition. The plates were then examined for clear zone of inhibition around the line of LAB and the clear zones were measured.

\section{Bacteriocin activity [16, 17]}

The selected strains were grown in MRS broth at $37^{\circ} \mathrm{C}$ for 24 hrs. Cell free supernatants were collected by centrifugation (8500 rpm, $10 \mathrm{~min}, 4^{\circ} \mathrm{C}$ ) of overnight MRS broth cultures. The $\mathrm{pH}$ value of the culture supernatant was adjusted to 7 
with $\mathrm{NaOH}(6 \mathrm{M})$ to eliminate the effect of organic acids. After adding catalase $(300 \mathrm{U} / \mathrm{ml})$ the cell free supernatants (pH 7) were incubated at $37^{\circ} \mathrm{C}$ for $1 \mathrm{hr}$ to eliminate the effect of hydrogen peroxide. Then they were heated at $90^{\circ} \mathrm{C}$ for 10 min to stop the enzyme reaction. The same supernatant without catalase were used as a control and all culture supernatant were filter sterilized to eliminate the possible presence of viable cells (modified).

The inhibition activity was examined by means of the diameters of inhibition zones using the agar well diffusion method. Briefly $10,15,20 \mu \mathrm{l}$ of the cell free supernatant were placed into a wells on the appropriate media agar plates which is seeded with indicator strains E. coli, Streptococcus aureus. After incubation of $24 \mathrm{hrs}$ the diameters of the inhibitory zones were measured.

\section{Production and Purification of Bioactive compound by using Column chromatography [18]}

The isolates were grown in a production media, MRS media for $24 \mathrm{hrs}$ at $37^{\circ} \mathrm{C}$. Then it was centrifuged at $8000 \mathrm{rpm}$ for 10 minutes. $400 \mathrm{~g}$ of ammonium sulphate per litre of culture supernatant were added and allowed to settle for $24 \mathrm{hrs}$ at $4^{\circ} \mathrm{C}$. The protein precipitate were collected by centrifugation at $6000 \mathrm{rpm} / \mathrm{min}$ for 20 minutes and dissolved in $50 \mathrm{ml}$ of 20 $\mathrm{mM} / \mathrm{L}$ sodium phosphate buffer $(\mathrm{pH}$ 6.0). Further it was applied on Diethylamino ethyl-cellulose column (1.5 x 40.0 $\mathrm{cm})$ equilibrated with $0.1 \mathrm{~m} / \mathrm{L}$ Tris-Hcl buffer $(\mathrm{pH}-9)$ and eluted with linear salt gradient of $\mathrm{Nacl}(0-1 \mathrm{~mol} / \mathrm{L})$ the active fractions were pooled together and concentrated by ammonium sulphate loaded on sephadex G-75 column $(1.5940 \mathrm{~cm})$ equilibrated with $0.1 \mathrm{~mol} / \mathrm{L}$ Tris-Hcl buffer (pH-9) and eluted with same buffer at a flow rate of $0.5 \mathrm{~mL} /$ minute and then eluted highest fractions were subjected to SDS-PAGE.

\section{SDS- PAGE [19]}

An intact SDS PAGE electrophoresis system should include: a tank, lid with power cables, electrode assembly, cell buffer dam, casting stands, casting frames, combs (usually 10-well or 15 -well) and glass plates (thickness $0.75 \mathrm{~mm}$ or $1.0 \mathrm{~mm}$ or $1.5 \mathrm{~mm})$.The SDS PAGE gel in a single electrophoresis run can be divided into stacking gel and separating gel. Stacking gel (acrylamide 5\%) is poured on top of the separating gel (after solidification) and a gel comb is inserted in the stacking gel. The acrylamide percentage in SDS PAGE gel depends on the size of the target protein in the sample. The samples were loaded in the gel and after running the samples were subjected to coomassie brilliant blue and the bands were observed.

\section{RESULTS AND DISCUSSION}

A number of strains of active lactic acid bacteria were isolated from raw goat and sheep milk. The strains which produce antimicrobial substance were detected by solid culture medium. These strains were screened for potential probiotic characteristics LAB.

\section{Screening of isolates:}

Cell surface hydrophobicity test - The degree of hydrophobicity of nine isolates (S3, G5, G9, G13, G14, G15, G17, G26, G27) has been determined and their results were tabulated (Table 1) shown in the figure 1.1. Bacterial surface features is one of the ex vivo properties that have been consorted with adherence to a variety of substrate, which in turn it is consorted with hydrophobicity. Bacterial attachment can also be used to influence the colonization potentiality of a microorganism. Through adhesion ability and colonization of tissues, probiotic microorganisms can forbid pathogen approach by steric interactions or particular occlusion on cell receptors [20]. The hydrophobicity of the cell directly proportional to the level of adhesion [21]. Reference [22] was compared and the result that 6 isolates are greater than $50 \%$ hydrophobicity which comes under the members of the genus Lactobacillus. In our study G5 isolate shows high degree of hydrophobicity and G17 isolate shows low degree of hydrophobicity. In nine isolates 6 strains shows greater than $50 \%$ hydrophobicity.

Phenol resistance test - These 9 strains showed growth in the presence of $0.4 \%$, phenol. Tolerance to phenol is a characteristic feature as phenols can be formed in the intestines by bacteria that de-aminate few aromatic amino acids delivered by the diet or produced by endogenous proteins [10]. In our study, the selected 9 strains S3, G5, G9, G13, G14, G15, G17, G26 and G27 were able to tolerate 0.4 $\%$ phenol. These 9 strains showed growth in the presence of $0.4 \%$, phenol. G9 shows more tolerance and G26 shows low tolerance. The result were tabulated (Table 1) and shown in the figure 1.2.

Antioxidant assay- The DPPH values were measured by the absorbance value at $517 \mathrm{~nm}$ for the various nine strains isolated from different raw goat milk samples. The results were tabulated (Table 1) and shown in the figure 1.3a. The DPPH assay is democratic in natural product antioxidant studies, method was mere and sensitive. This assay was founded on the theory that a hydrogen donor is antioxidant. It evaluates the compounds that are radical scavengers [11].Total antioxidant assay were examine often which is used to approach the antioxidant position of biological sample and can analyze the antioxidant reaction versus the free radicals developed [12]. The total antioxidant assay was measured by the absorbance value at $695 \mathrm{~nm}$ for the various nine strains for total antioxidant assay (Figure 1.3b).

Cholesterol reducing activity - Several studies have strongly proposed that fermented milk could lower total cholesterol and low density lipoproteins (LDL) cholesterol 
thus having a hypocholesterolemic effect [23,24]. The number of cholesterol absorption by these probiotic organisms brought out a broad fluctuation (29-57\%) quantity of the strains. In another study of L. yoghurt has highest $(\mathrm{p}<0.05)$ cholesterol absorption capacity while $L$. casei showed moderate and L. choozti shows the least [25]. Therefore it is indicated that probiotic can also be used to treat hyper cholesterolemic patients, thus reducing the heart attacks. In our study of nine isolates G9 shows high cholesterol reducing activity, G5 shows low cholesterol reducing activity and other isolates shows moderate activity. The cholesterol reducing activity of various isolates were measured at $560 \mathrm{~nm}$, the results were tabulated (Table 1) and shown in the figure 1.4 .

Table 1.Probiotic Evaluation profile of the isolates

\begin{tabular}{|c|c|c|c|c|c|c|}
\hline \multirow{2}{*}{$\begin{array}{l}\text { S. } \\
\text { No }\end{array}$} & \multirow[t]{2}{*}{ Strain } & \multicolumn{2}{|c|}{ Antioxidant assay } & \multirow{2}{*}{$\begin{array}{l}\text { Phenol } \\
\text { resistanc } \\
\text { e test }\end{array}$} & \multirow{2}{*}{$\begin{array}{l}\text { Cell } \\
\text { surface } \\
\text { hydroph } \\
\text { obicity }\end{array}$} & \multirow{2}{*}{$\begin{array}{l}\text { Choles } \\
\text { terol } \\
\text { reducing } \\
\text { activity }\end{array}$} \\
\hline & & DPPH & $\begin{array}{l}\text { Total } \\
\text { antioxi } \\
\text { dant }\end{array}$ & & & \\
\hline 1 & S3 & 0.321 & 0.202 & 0.29 & 46.362 & 0.278 \\
\hline 2 & G5 & 0.449 & 0.342 & 0.13 & 88.746 & 0.034 \\
\hline 3 & G9 & 0.270 & 0.418 & 0.28 & 57.204 & 0.718 \\
\hline 4 & G13 & 0.292 & 0.396 & 0.12 & 58.422 & 0.416 \\
\hline 5 & G14 & 0.234 & 0.396 & 0.18 & 40.926 & 0.293 \\
\hline 6 & G15 & 0.437 & 0.189 & 0.13 & 57.297 & 0.072 \\
\hline 7 & G17 & 0.331 & 0.293 & 0.14 & 19.256 & 0.276 \\
\hline 8 & G26 & 0.208 & 0.414 & 0.09 & 66.975 & 0.412 \\
\hline 9 & G27 & 0.444 & 0.542 & 0.25 & 72.607 & 0.014 \\
\hline
\end{tabular}

Auto aggregation and co aggregation- Based on the probiotic evaluation of G13 was subjected to aggregation study. Sedimentation rate of G13 isolates was determined for a period of 24 hours and the auto aggregation and co aggregation of G13 was measured which shown in the figure 2. Auto aggregation possible of cells acts a significant function in attachment to enteric cells [26] and prevents the infectious agent colonization.

Probiotics should have auto aggregation possibility over $40 \%$. In our study G13 isolates showed affinity over $40 \%$ (i.e., 56\%). Among 9 isolates, G13 showed highest affinity. This confirms the ability of G13 to adhere, persist and divide in GIT, qualifying it as potential probiotic. Co aggregation tests plays simple and authentic methods relevant to a large number of the test strains for screening Lactobacillus as described in [27].

\section{CELL SURFACE HYDROPHOBICITY}

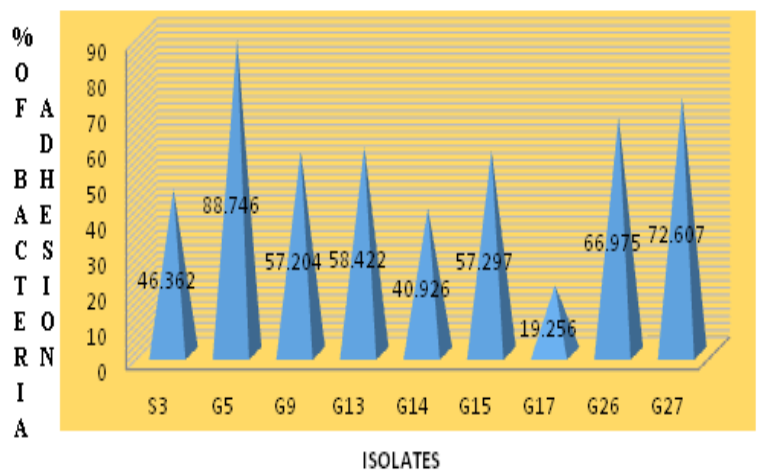

Fig 1.1: Cell surface hydrophobicity test

\section{PHENOL RESISTANCE TEST}

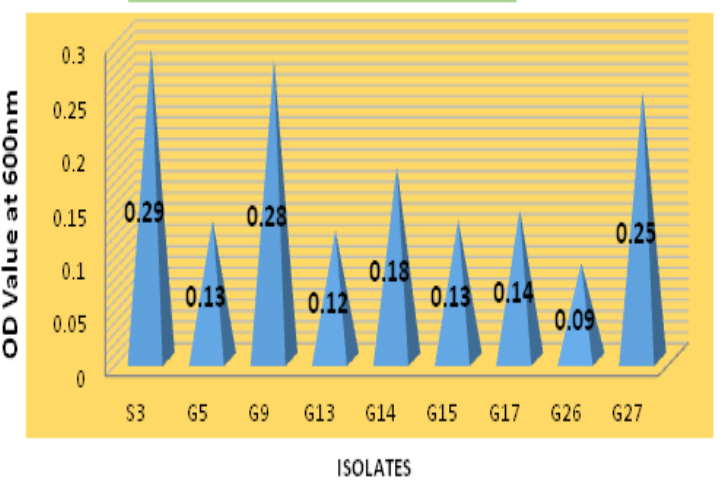

Fig 1.2: Phenol resistance test DPPHASSAY

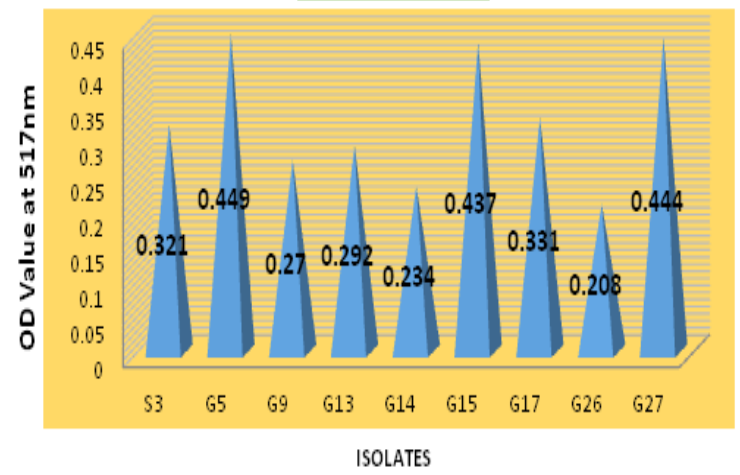

Fig 1.3a: Antioxidant assay-DPPH 


\section{TOTAL ANTIOXIDENT ASSAY}

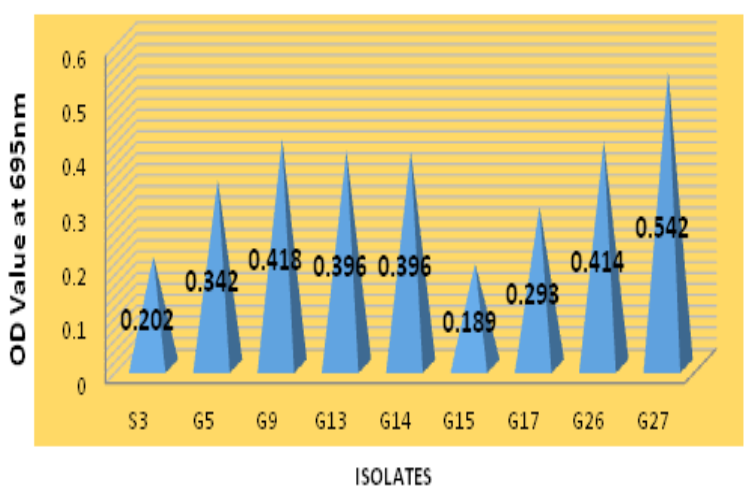

Fig 1.3b: Total antioxidant assay

\section{CHOLESTROL REDUCING ACTIVITY}

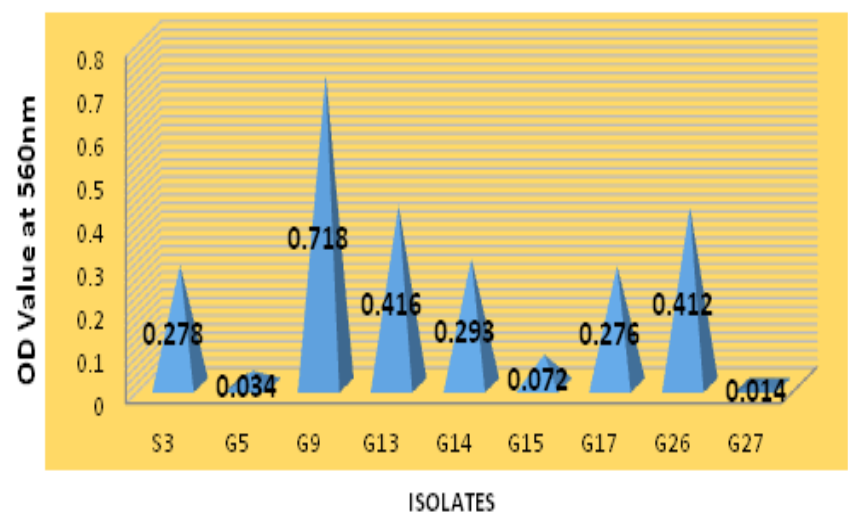

Fig 1.4: Cholesterol reducing activity

Figure 1: Graphical analysis of Probiotic evaluation profile of the goat milk isolates

These attributes are believed to be associated to the ability to act intimately with unsuitable bacteria. Thus in study of the probiotic from chicken gut, the organism Lactobacillus salivarious gives high coaggregation [28]. In our study the isolate G13 gives $35.75 \%$ when interact with E.coli and $57.05 \%$ when interact with Staphylococcus aureus.

Antimicrobial activity-The diameters of inhibition zones showed that all the isolates have antibacterial effects against the tested pathogens were tabulated (Table 2) and shown in the figure 3. Antimicrobial activity against pathogens desolating goat production is a suitable attributes of a probiotic strain to be used in goat's farming. Antibacterial activity is life sustaining for the successful colonization of lactobacilli in the intestinal mucosa as they allow a barrier effect and defence against pathogens [29]. Lactobacillus may obtain antimicrobial effect by producing some substances such as organic acids, ( lactic, acetic, propionic) carbon dioxide, hydrogen peroxide, diacetyl, low molecular weight antimicrobial substances such as bacteriocins, which may be endlessly excreted by the bacteria to produce the inhibitor activity versus the pathogens [30].

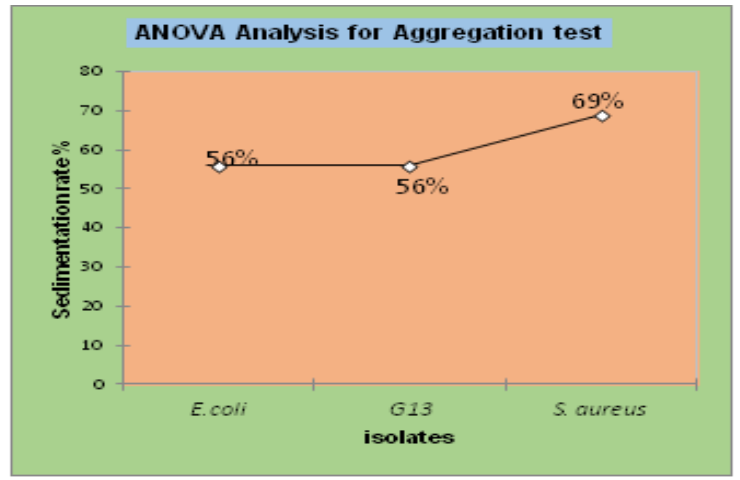

Fig 2.1: Auto aggregation assay

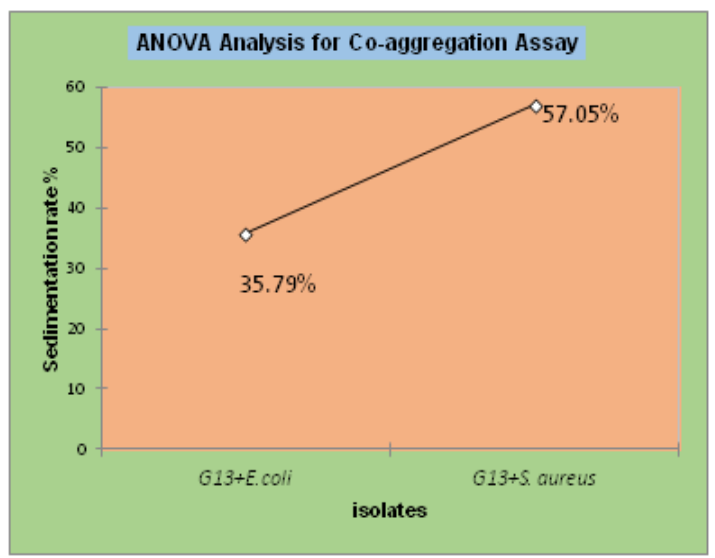

Fig 2.2: Co-aggregation assay

Figure 2: ANOVA analysis for Aggregation Study

The antibacterial activity of the cell free supernatants prevailed from the G5 and G13 probiotic isolates were tested by agar well diffusion method against $E$. coli, $S$. aureus and Candida albicans as selected pathogens of importance in goat's farming. The antimicrobial activity produced by the 2 isolates in this study demonstrated inhibition of growth for $E$. coli, S. aureus and C. albicans. The two isolates have inhibition zones with diameter of $7 \mathrm{~mm}$ and $9 \mathrm{~mm}$ against $S$. aureus for G5 and G13, no zone and $7 \mathrm{~mm}$ against $E$. coli and show no zone for G5 and G13 against $C$. albicans.

Table 2: Antimicrobial activity

\begin{tabular}{|l|l|l|}
\hline Organisms & G5 & G13 \\
\hline E.coli & $10 \mathrm{~mm}$ & $14 \mathrm{~mm}$ \\
\hline $\begin{array}{l}\text { Staphylococcus } \\
\text { aureus }\end{array}$ & $9 \mathrm{~mm}$ & $8 \mathrm{~mm}$ \\
\hline Candida albicans & No Zone & No zone \\
\hline
\end{tabular}




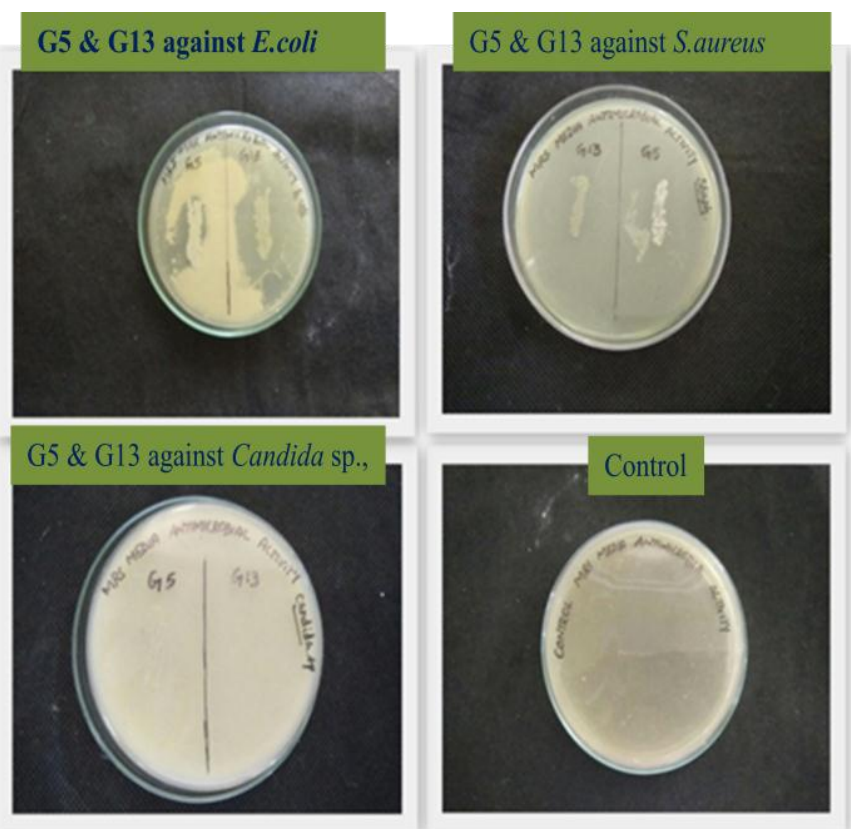

Figure 3:Plates of Antimicrobial activity

Column chromatography -Using column chromatography were the protein purified from the G13 isolate, their fractions were tabulated (Table 4.11.) and the highest fraction has taken for SDS-PAGE analysis to know the molecular weight of the protein produced by G13 isolate in the crude.

Table 3: Fraction obtained from chromatography

\begin{tabular}{|l|l|}
\hline S.NO & $\begin{array}{l}\text { FRACTIONS } \\
(\mathbf{2 8 0 n m})\end{array}$ \\
\hline 1 & 0.239 \\
\hline 2 & 0.430 \\
\hline 3 & $\mathbf{0 . 4 5 2}$ \\
\hline 4 & 0.381 \\
\hline 5 & 0.436 \\
\hline
\end{tabular}

Cell-free supernatant antibacterial assay-The antibacterial activity of the cell free supernatants obtained from the isolates were tested by agar well diffusion method against $E$. coli and $S$. aureus. In this study manifested inhibition of growth for $E$. coli and $S$. aureus. The inhibitory agents produced by the isolated LAB examined in this study could be characterized as bacteriocins like, since inhibition due to acid have been excluded. Results shown in table 4 . The well diffusion method was done to determine the bacteriocin activity of the LAB cultures. The bacteriocin produced and was purified and the sensitivity to test organism were carried out thus in the study L.plantarum and L.brevis shows high inhibition against the E.coli and Salmonella sp [31].

Table 3.Cell free crude antibacterial agar well diffusion assay

\begin{tabular}{|l|l|l|l|l|l|l|l|l|}
\hline $\begin{array}{l}\text { Test } \\
\text { Organism }\end{array}$ & $\begin{array}{l}10 \\
\mu \mathrm{L}\end{array}$ & $\begin{array}{l}15 \\
\mu \mathrm{L}\end{array}$ & $\begin{array}{l}20 \\
\mu \mathrm{L}\end{array}$ & $\begin{array}{l}\mathrm{pH} 7 \\
10 \mu \\
\mathrm{L}\end{array}$ & $\begin{array}{l}\mathrm{pH} 7 \\
15 \mu \\
\mathrm{L}\end{array}$ & $\begin{array}{l}\mathrm{pH} 7 \\
20 \mu \\
\mathrm{L}\end{array}$ & $\begin{array}{l}\text { MRS } \\
\text { contrl }\end{array}$ & $\begin{array}{l}\text { MRS } \\
\mathrm{pH} 7 \\
\text { contro } \\
1\end{array}$ \\
\hline E.coli & $\begin{array}{l}4 \\
\mathrm{~m} \\
\mathrm{~m}\end{array}$ & $\begin{array}{l}6 \\
\mathrm{~m}\end{array}$ & $\begin{array}{l}6 \\
\mathrm{~m}\end{array}$ & $\begin{array}{l}\mathrm{m} \\
\mathrm{m}\end{array}$ & $\begin{array}{l}5 \\
\mathrm{~mm}\end{array}$ & $\begin{array}{l}6 \\
\mathrm{~mm}\end{array}$ & $\begin{array}{l}\text { No } \\
\text { zone }\end{array}$ & $\begin{array}{l}\text { No } \\
\text { zone }\end{array}$ \\
\hline $\begin{array}{l}\text { Staphyloc } \\
\text { occus } \\
\text { aureus }\end{array}$ & $\begin{array}{l}5 \\
\mathrm{~m}\end{array}$ & $\begin{array}{l}7 \\
\mathrm{~m}\end{array}$ & $\begin{array}{l}\mathrm{m} \\
\mathrm{m}\end{array}$ & $\begin{array}{l}\text { No } \\
\mathrm{Z}\end{array}$ & $\begin{array}{l}4 \\
\mathrm{~mm}\end{array}$ & $\begin{array}{l}7 \\
\mathrm{~mm}\end{array}$ & $\begin{array}{l}\text { No } \\
\text { zone }\end{array}$ & $\begin{array}{l}\text { No } \\
\text { zone }\end{array}$ \\
\hline
\end{tabular}

SDS -PAGE - Considering bacteriocin production, cell growth was started from late log phase itself and maximum was obtained in early stationary growth phase at 30th hr of the culture. Growth beyond the stationary phase resulted decrease in bacteriocin production. In purification bacteriocin from culture supernatant was concentrated by ammonium sulphate precipitation followed by cation exchange chromatography and hydrophobic interaction chromatography. From this study the five fraction were collected and the highest fraction 0.452 were screened. Single protein bands were observed when stained with coomassie brilliant blue and it clearly indicated the purity of the protein. SDS-PAGE analysis showed an electrophoretically pure protein with an apparent molecular size of $17 \mathrm{kDa}$ which shows the present of low molecular weight protein. The molecular weight of the purified bacteriocin of G13 isolates was estimated at $17 \mathrm{kDa}$ (Figure 4) by SDS- PAGE.

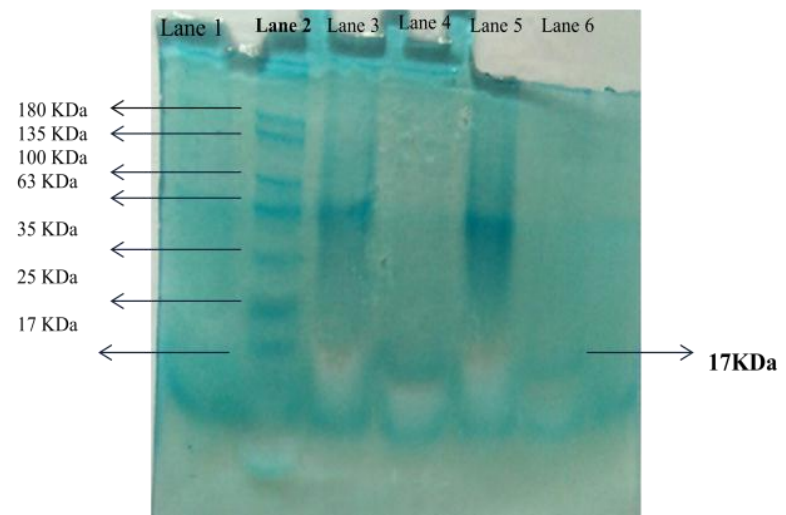

Figure 4: Molecular weight of the purified bacteriocin from $G 13$ by SDS-PAGE.

\# Note: lane 1 - blank, lane 2-marker, lane 3-crud of other isolate, lane 4-band of other isolate purified sample, lane 5-crude of G13 and lane 6-G13 isolates purified sample.

UV-Visible spectrometric analysis- Bacteriocins produced by Lactic acid bacteria were come under 10KDa such as nisin $(3,5 \mathrm{KDa})$, lactisin(4,5KDa), lactacin(6,8KDa), Lactocin (3,7 KDa), sakacin P (4,4KDa) and Helveticin (<30 $\mathrm{KDa})$ reported in [32] and reported L.murinus AU06 produced $21 \mathrm{KDa}$ protein[18]. In our study purified protein from G13 antibacterial compound molecular weight $17 \mathrm{KDa}$. It may be a novel protein produced by lactic bacteria. 
Accourding to the UV-VIS Spectrophotometry analysis (Figure 5) our sample showed $280 \mathrm{~nm}$, so they were proteinaceous nature compound. Protein absorb in 240 $300 \mathrm{~nm}$ based on the presence of amino acid [33].

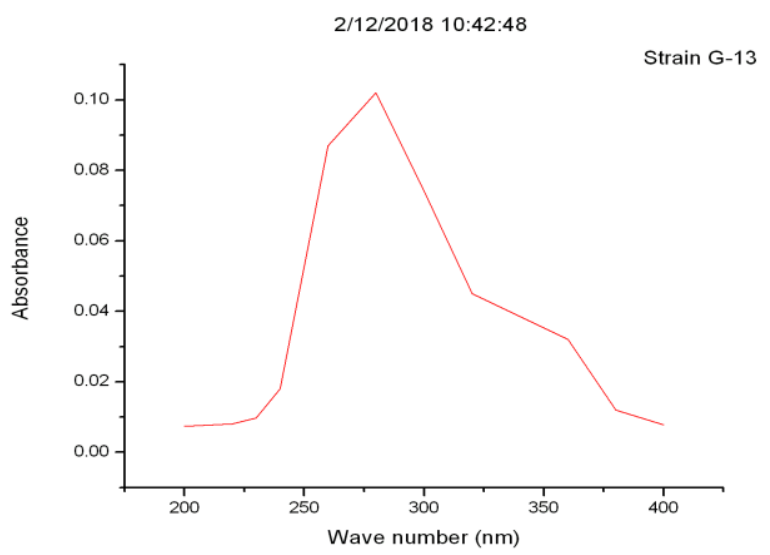

Figure 5: Microprocessor UV-VIS SPEC single beam
analysis of band of G13 sample from SDS-PAGE

\section{CONCLUSION AND Future SCOPE}

The present study has concluded that most of the strains isolated from raw goat and sheep milk possess good probiotic characteristic.G13 isolate producing antimicrobial compound showed $17 \mathrm{KDa}$ molecular weight protein. It may be a novel protein, needs further compound analysis. Further work required to carry out safety zone measurement of using probiotic bacteria in food industry.

\section{Conflict of interest}

None

\section{ACKNOWLEDGMENT}

This work was carried out in CBNR Laboratory, Coimbatore TN. Special thanks to Dept.of Microbiology, Tiruppur Kumaran College for Women, Tirupur and Hidusthan College of Arts and Science, Coimbatore. My Heart full thanks to G.Senbagam.

\section{REFERENCES}

[1] $\mathrm{FAO} / \mathrm{WHO}$, "Guidelines for the evaluation of probiotics in food. London, Ontario. Canada, April 30 and May 1, 2002.

[2] $\mathrm{FAO} / \mathrm{WHO}$, "Health and nutritional properties of probiotics in food including powder milk with livelactic acid bacteria", Cordoba, Argentina, 1-4 October 2001.

[3] Subhashini, "Bioprospecting of LAB for potentiality as probiotics", International Journal of Microbiological Research 5(2) , 90-97,DOIL:10.5829/idosi.ijmr.2014.5.2.83291,2014

[4] Kim HJ; Shin HS; Ha WK; Yang IH; Lee SW, "Characterization of Lactic bacterial strains isolated from raw milk", Asian-Aust $J$ Anim Sci, 19, 131-136.2006.
[5] Tiiu Kullisaar, Epp Songisepp, Marika Mikelsaar, Kersti Zilmer, Tiiu Vihalemm and Mihkel Zilmer, British Journal of Nutrition 90: 449-456,2003.

[6] Clevaland, J., Montiville, T.J., Nes, I.F. and C hikindas, M.L, "Bacteriocins: Safe, Natural Antimicrobials for Food Preservation", International Journal of Food Microbiology, 71, 120,2001.

[7] Selvajeyanthi S and Hemashenpagam N, "Screening of indigenous active lactic acid bacteria isolated from freshly drawn raw milk", Bioscience Biotechnology Research Communications, Vol.11(3),426-433,2018. DOI: $10.21786 / \mathrm{bbrc} / 11.3 / 11$

[8] Dilna SV, Aswathy RG, Surya H, Varsha KK, Sakthikumar DN, "Characterization of an exopolysaccharide with potential healthbenefit properties from a probiotic Lactobacillus plantarum RJF4", LWT Food Sci Technol, 1179-1186,2015.

[9] Thapa P.B,Gideon P,Cost T.W,William A.B and Ray W.A, The New England journal of medicine ,339,875-882,1998.

[10] Pooja Thakkar, H. A. Modi and J.B. Prajapati, "Isolation, characterization and safety assessment of lactic acid bacterial isolates from fermented food products", Int J. Curr. Microbiol. App. Sci Vol 4 issue 4; pg no: 713-725,2015.

[11] Gurushree Soundararajan, N.G.Ramesh Babu, Jesteena Johney, R.Ranganathan , "Extraction of Bioactive Compounds from Rosmarinus officinalis and its Anticancer Activity against Hela cell line", International Journal of Science and Research (IJSR), $165-168,2017$.

[12] Susan K Thomas, Jesteena Johney and Ragunathan R , "EcoFriendly synthesis of silver nanoparticle using Banana (Musa Acuminate Colla) peel, its phytochemical, Antimicrobial and Anticancer activity", International journal of recent scientific research, pp.21098-21106,2017.

[13] Zlatkis, A., Zak, B., Boyle, G.J, "A new method for direct determination of serum cholesterol", Journal of laboratory and clinical medicine, Vol 41: pp.486,1953.

[14] Murua, A., Todorov, S.D., Vieira, A.D.S., Martinez, R.C.R., Cencic, A. and Franco. B.D.G.M., "Isolation and identification of bacteriocinogenic strain of Lactobacillus plantarum with potential beneficial properties from donkey milk", Journal of Applied Microbiology, pp.1364-5072,2013.

[15] Bolanle A. Adeniyi, Adewale Adetoye, Funmilola A. Ayeni, "Antimicrobial activities of lactic acid bacteria isolated from cow faeces against potential enteric pathogens", African health sciences Vol 15 issue 3: pp.888-895,2015.

[16] Gurban oglu Gulahmadov, S., Batdorj, B., Dalgalarronda, M, European Food Research and Technology, Volume 224: pp.229235,2006.

[17] Musikasang H., Sohsomboon N., Tani A. and S. Maneerat, "Bacteriiocin - producing lactic acid bacteria as a probiotic potential from Thai indigenous chickens", Czech J. Anim. Sci., Vol 57 issue3;pg no: 137-149,2012.

[18] Sivaramasamy Elayaraja, Neelamegam Annamalai, Packiyam Mayavu, and Thangavel Balasubramanian, " Production, purification and characterization of bacteriocin from Lactobacillus murinus AU06 and its broad antibacterial spectrum", Asian Pac J Trop Biomed; 4(Suppl 1): S305-S311,2014.

[19] Schagger H and G. Von Jagow, " Tricine-sodium dodecyl sulphate polyacrylamide gel electrophoresis for the separation of proteins in the range from 1 to $100 \mathrm{kDa}$ ", Anal. Biochem. 166:368-379,1987.

[20] Otero, M.C., Ocana, V.S., and E.N.M. Macias , Methods in Molecular Biology, Vol 268;pp. 435-440,2004.

[21] Rijnaarts H. H. M Norde, W Bouwer, E. J Lyklema and A. J. B. Zehnder, Applied and Environmental Microbiology. Vol 59; pp 3255-3265,1993. 
[22] Valeriano V.D., Parungao-Balolong M.M., and D.K.Kang,"In vitro evaluation of the mucin-adhesion ability and probiotic potential of Lactobacillus mucosae LMI", J. Applied Microbiology, Vol 117; pp. 485-497,2014.

[23] Anderso JW,Gilliland SE, "Effect of fermented milk(yoghurt) containing Lactobacillus acidophilus L1 on serum cholesterol in hypercholesterolemic humans",J Am Coll Nutr,Vol.18,pp.43$50,1999$.

[24] Sanders M.E , "Overview of functional foods: emphasis on probiotic bacteria", Int Dairy J., 8: 341-347,1998.

[25] Geeta Shukla, Gatha Sharma and Nisha Goyal , "Probiotic characterization of Lactobacilli and yeast strains isolated from Whey beverage and Therapeutic potential of Lactobacillus yoghurt in Murine Giardiasis", American journal of biomedical sciences. 2(3), 248-261,2010.

[26] Dunne C, O’Mahony L, Murphy L, Thomton G, Morrissey D“In vitro selection criteria for probiotic bacteria for human origin: Correlation with in vivo findings", Am J Clin Nutr 73: 386$392,2001$.

[27] Carlos Gusils,Genga oliver silvia N.Gonzalez, "Some probiotic properties of chicken lactobacillus", Canadian journal of Microbiology,Vol 45(12),pp.981-987,1999

[28] Andri Hutari, Waleed Shaker Jaseem, Aidil Abdul Hamid and Wan Mohtar Wan Yusoff, "Screening of Lactobacillus strains against Salmonella both isolated from Malaysian free-range chicken intestine for use as probiotic", Sains Malaysiana, Vol 40(10); pp. 1115-1122,2011.

[29] Vaughan E E, Mollet B and Devos W M, "Functionality of Probiotics and intestinal lactobacilli: light in the intestinal tract tunnel", Current Opinion in Biotechnology 10: 505-510,1999.

[30] Santos A, Mauro M.S, Sanchez, A., Torres, J.M., and Marguina D, "The antimicrobial properties of different strains of Lactobacillus spp isolated from kefir", Systematic and Applied Microbiology Vol 26(3): pp.434-437,2003.

[31] Ogunbanwo, S. T., Sanni, A. L. and A. A. Onilude, "Characterization of bacteriocin produced by Lactobacillus plantarum F1 and Lactobacillus brevis OG1", African journal of Biotechnology Vol 2 issue 8; pp. 219-227,2003.

[32] Jose Luis Parada,Carolina Ricoy Caron,Adriane Bianchi P.Mederiros and Carlos Ricardo Soccol, "Bacteriocins from LAB:Purification,Properties and use as biopreservatives", An international journal of Brazillian Archives of Biology and Technology,Vol 50,no.3,pp.521-542,2007.

[33] Franz-Xaver Schmid, "Biological macromolecules:UV-Visible Spectrophotometry", Encyclopedia of life sciences Macmillian Publishers Ltd., Nature publishing group/www.els.net.,2001.

\section{AUTHORS PROFILE}

Ms.S.Selvajeyanthi,B.Sc.,M.Sc.,Ph.D (pursuing-part time) in Microbiology. She is currently working as Assistant Professor in Department of Microbiology, Tiruppur Kumaran College for Women,Tirupur,TN,India. She has 3 years of teaching experience. Main research focus on lactic acid bacteria,Probiotic bacteria and novel finding.Guided M.Sc.,Microbiology students.Recipient of IASc-INSA-NASI summer Research Fellow in the year 2012. She has attended and presented posters and papers in many conferences and seminars.Achieved best paper award in Next generation probiotic-2019 workshop held at CSIR-CFTRI,Mysore.Peer reviewed in Biotechnology Journal International,South Asian Journal of Research in Microbiology,Journal of Advances in Microbiology,Asian Food Science Journal and Journal of scentific Research and Reports. 